\title{
Comparison of Different Sampling Techniques for the Identification of Aromatic Hydrocarbons from Fire Effluents
}

\author{
Abdulrhman M. Dhabbah ${ }^{1}$, A. Yacine Badjah-Hadj-Ahmed ${ }^{2}$, Anna A. Stec ${ }^{3}$, T. Richard Hull ${ }^{3}$ \\ ${ }^{1}$ King Fahd Security College, Riyadh, Kingdom of Saudi Arabia \\ ${ }^{2}$ Chemistry Department, College of Science, King Saud University, Riyadh, Kingdom of Saudi Arabia \\ ${ }^{3}$ Centre for Fire Hazards and Science, School of Physical Sciences and Computing, University of Central Lancashire, Preston, UK \\ Email: *a_dhabbah@hotmail.com
}

How to cite this paper: Dhabbah, A.M., Badjah-Hadj-Ahmed, A.Y., Stec, A.A. and Hull, T.R. (2019) Comparison of Different Sampling Techniques for the Identification of Aromatic Hydrocarbons from Fire Effluents. American Journal of Analytical Chemistry, 10, 23-37.

https://doi.org/10.4236/ajac.2019.101003

Received: December 9, 2018

Accepted: January 19, 2019

Published: January 22, 2019

Copyright $\odot 2019$ by author(s) and Scientific Research Publishing Inc. This work is licensed under the Creative Commons Attribution International License (CC BY 4.0).

http://creativecommons.org/licenses/by/4.0/

\begin{abstract}
Huge amounts of various polymers are being used in many fields with numerous benefits. However, their great ability to ignition and rapid flame spreading make these materials dangerous for human life and properties due to the release of highly toxic combustion products. The present work aims to investigate several methods of sampling and identification of aromatic hydrocarbons produced by controlled burning of low-density polyethylene (LDPE) using a toxicity tube furnace. Five different sampling methods were used: solid phase micro extraction (SPME), syringe, tedlar bags, sorption tubes, and gas-solution absorbers (midget impingers). The produced hydrocarbons were analysed by gas chromatography coupled to mass spectrometry with and without pyrolysis. Among the tested techniques, the most convenient sampling method was using syringe with a glass vessel which allowed detection of the highest amount of aromatic hydrocarbons at both $800^{\circ} \mathrm{C}$ and $600^{\circ} \mathrm{C}$, and then followed by SPME. On the other hand, the use of gas-solution absorber (midget impinger) showed poorer results. Regarding the use of tedlar bags and sorption tubes, they did not give satisfactory results. Several carcinogenic or possibly carcinogenic compounds were identified in the combustion products, such as benzene, naphthalene, anthracene and pyrene.
\end{abstract}

\section{Keywords}

Polyethylene, Combustion, Fire Effluents, Sampling,

Polycyclic Aromatic Hydrocarbons, GC-MS

\section{Introduction}

For several decades, increasing quantities of synthetic polymeric materials have 
been used in various fields, such as construction, transport, electrical and electronic equipment, furniture etc. Unfortunately, the benefits and wide range of application of these materials are undermined by their great liability for ignition and flame spreading, which are accompanied by the release of toxic combustion products [1]. In fire atmospheres, fire effluents (toxic gases, visible smoke, and heat) play a crucial role negatively affecting the environment and life safety of many creatures [2].

Exposure to fire effluents and smoke may cause acute and chronic toxicities. The acute effects can occur immediately whereas the chronic manifestations appear over an extended period of time [1] [3] [4] [5]. This usually happens either after inhalation of particulate matters which are sufficiently small to penetrate and accumulate in the respiratory tract or inspiration of the generated smoke, leading to impaired vision, or breathing difficulties with severe pain in multiple organs including eyes, nose, throat and chest [3] [6].

Acute toxicity may occur after a single exposure to a toxic substance following inhalation of a single dose or more than one within $24 \mathrm{~h}$ [1] [7]. On the other hand, chronic exposure depends on the accumulated doses occurring after continuous or repeated exposure to a toxin over an extended period ranging from months to years, causing irreversible toxic effects [8]. The chronic toxicants may exhibit a range of morbidities due to respiratory sensitizers (such as isocyanates) or teratogenic and mutagenic effects, such as those caused by halogenated dibenzo-p-dioxins and dibenzofurans. Other chronic toxicants, which are considered as carcinogens, include aromatic hydrocarbons compounds. They are formed and released in fires, mainly due to incomplete combustion, and can be divided into two categories: volatile organic compounds (VOCs) such as benzene, and semi-volatile organic compounds (SOVCs) including polycyclic aromatic hydrocarbons (PAHs) such as naphthalene, benzo(a)pyrene and 2-nitrophenol [1] [9].

A proper fire effluent sampling system should give a representative and realistic sample of the test atmosphere, without affecting this sample. This depends on a number of factors including nature of the species, the temperature, the length and type of material used for sampling. Therefore, it is necessary to take these factors into account when sampling and analysing a fire effluent to ensure accurate identification and quantification of fire effluent products [10] [11] [12].

For generating aromatic hydrocarbons in fire, certain specific instruments should be used to simulate different fire conditions: non-flaming, well-ventilated flaming and under-ventilated flaming conditions.

As an example, at $600^{\circ} \mathrm{C}$ the rate of burning is almost steady and the process is well ventilated, while at $800^{\circ} \mathrm{C}$ the pyrolysis rate is higher, and it can be regarded as under-ventilated [13].

As an example, it is possible to produce aromatic hydrocarbons under a wide range of fire conditions using a toxicity tube furnace (Model NFX70-100, developed by Concept Equipment, UK) [14]. On the other hand, different methods 
can be used for trapping and sampling individual aromatic hydrocarbons, such as: gas-solution absorbers (midget impingers), solid phase micro-extraction (SPME), sorption tubes, tedlar bags and syringe [12].

Gas solution absorbers (also known as midget impingers) are one of the most common methods which are designed as bubble tubes used for collecting gaseous chemicals into a liquid solution. In this sampling technique, a known volume of air is bubbled through the impinger containing a specific solvent which will chemically react with or physically dissolve the chemical of interest [15]. Solid-phase microextraction (SPME) which was developed by Pawliszyn in 1989, may be also used to collect gases from fire effluent. It is a simple, fast and solventless extraction technique and proved to be a good alternative to traditional extraction methods. SPME uses a special syringe containing a fused silica fiber coated with a suitable polymer [16] [17]. When immersed in a liquid sample or exposed to volatile components emitted from a liquid or solid matrix, the fiber adsorbs and concentrates the volatile compounds. Solid sorption tube is another method for sampling combustion gases including aromatic hydrocarbons. This technique is based on adsorption of volatile and semi-volatile analytes on a solid sorbent packed in a tube, followed by their desorption step using heat and a flow of inert gas. It proved to be a sensitive sampling technique which can be used instead of traditional concentration methods such as desorption by solvent [18].

After sampling aromatic hydrocarbons by one of the previously cited methods, they are analyzed by gas chromatography coupled with mass spectrometry (GC-MS). In the case of effluent gas collected on sorption tube, it can be analyzed by insertion of it in a pyrolysis instrument connected to a gas chromatograph coupled with a mass spectrometer (Py-GC-MS). GC-MS is a versatile and highly sensitive analytical technique used in many fields. GC-MS combines the advantages of high-resolution capillary columns with the excellent properties of mass spectrometers. It is very useful for elucidation of complex samples with high sensitivity, selectivity and specificity [19].

As mentioned earlier, pyrolysis can be coupled to GC-MS for investigation of thermal degradation of various organic samples. In fire effluent detection, this method can be used to thermally degrade the sample to produce smaller fragments that are separated on a GC column then detected in a mass spectrometer. Py-GC/MS is particularly useful for examination of combustion products resulting from burning polymeric materials that are difficult to dissolve in a solvent [20].

The present study aims to investigate the combustion products resulting from burning low-density polyethylene (LDPE), which is widely used in many fields such as industry and household furniture, by using five different sampling techniques in order to compare them. These methods were: gas-solution absorbers (midget impingers), solid phase micro-extraction (SPME), syringe, tedlar bags and sorption tubes, while the analysis was carried out by gas chromatography 
coupled to mass spectrometry and focused on aromatic hydrocarbons. The experimental conditions used for each technique were selected according to previous studies [21] [22] [23] [24] [25].

\section{Experimental}

Producing aromatic hydrocarbons under a wide range of fire conditions was achieved using a toxicity tube furnace (Model NFX70-100, developed by Concept Equipment, UK) (Figure 1) [14]. This instrument was developed to produce and estimate pyrolysis or combustion effluents under specific laboratory conditions. Thus, it is a small scale static tube furnace in which the test specimen (typically $1 \mathrm{~g}$, or $0.1 \mathrm{~g}$ for low density materials), is pushed in a crucible, into the middle of the furnace tube and then heated to temperatures of $600^{\circ} \mathrm{C}$ or $800^{\circ} \mathrm{C}$, with flowing air at 2 litres per min.

The controlled combustion of low-density polyethylene (LDPE) was carried out by burning $1.00 \mathrm{~g}$ in toxicity tube furnace (Model NF X70-100) at $800^{\circ} \mathrm{C}$ and $600^{\circ} \mathrm{C}$. The combustion products were then trapped and sampled using gas-solution absorbers (midget impingers), solid phase micro extraction (SPME), syringe, sorption tubes and tedlar bags [12]. A picture of each sampling device is shown in Figure 2 .

The detailed experimental parameters used in sampling and analysis of fire effluents are given in Table 1. Table 2 and Table 3 show the conditions used for collecting the fire effluents produced at $800^{\circ} \mathrm{C}$ and $600^{\circ} \mathrm{C}$. The collection procedures based on SPME and syringe, used in the present work, were described in Bulletin 922 from Supelco [21]. In the case of gas-solution absorption, the sampling was carried out by methods described in EPA 8270D and EPA 8275 [22] [23]. All these sampling methods were followed by gas chromatography hyphenated to mass spectrometry (GC-MS), except experiments based on sorption tubes in which the effluents were analyzed by using pyrolysis-gas chromatography-mass spectrometry (Py-GCMS) according to methods described in EPA TO-15 and EPA TO-17 [24] [25]. Below is a brief summary to describe the different methods used.

\subsection{Sampling Using Gas-Solution Absorbers}

In this method, collection of fire effluents for absorption of gases in solution was

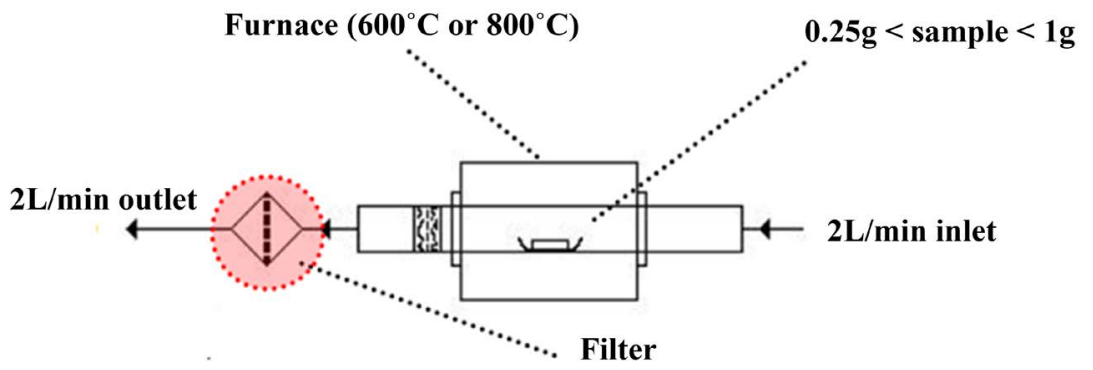

Figure 1. Toxicity tube furnace NF X 70-100. 


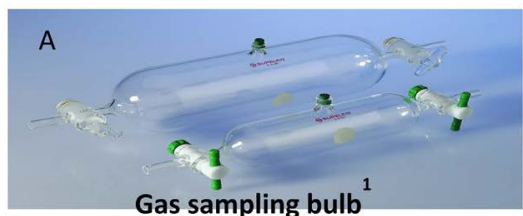

Gas sampling bulb

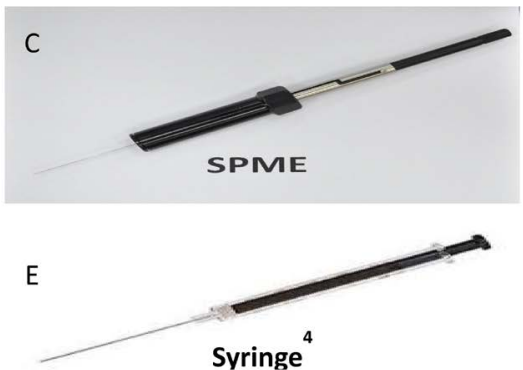

1-https://www.sigmaaldrich.com/catalog/product/supelco/22144u?lang=en\&region=SA 2-https://www.techinstro.com/tedlar-bag/\#

3-https://www.sigmaaldrich.com/catalog/product/supelco/28281u?lang=en\&region=SA 4-http://www. fishersci.com/ecomm/servlet/itemdetail?catnum $=14685200$ 5-https://www.thomassci.com/Laboratory-Supplies/Gas-Washing-Bottles//31760125EC-BOT/COMP-125ECCS1-CORNING
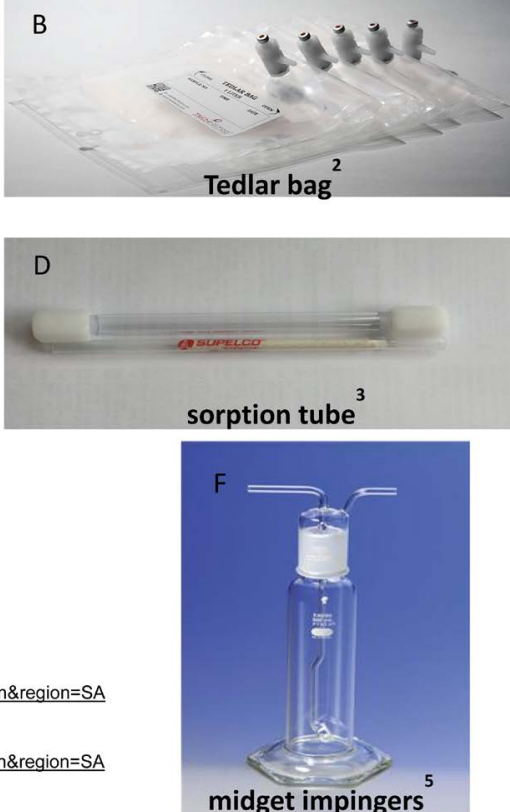

Figure 2. Pictures showing the different sampling devices used in the present work.

Table 1. Experimental parameters for analysing LDPE combustion products by GC-MS and Py-GCMS.

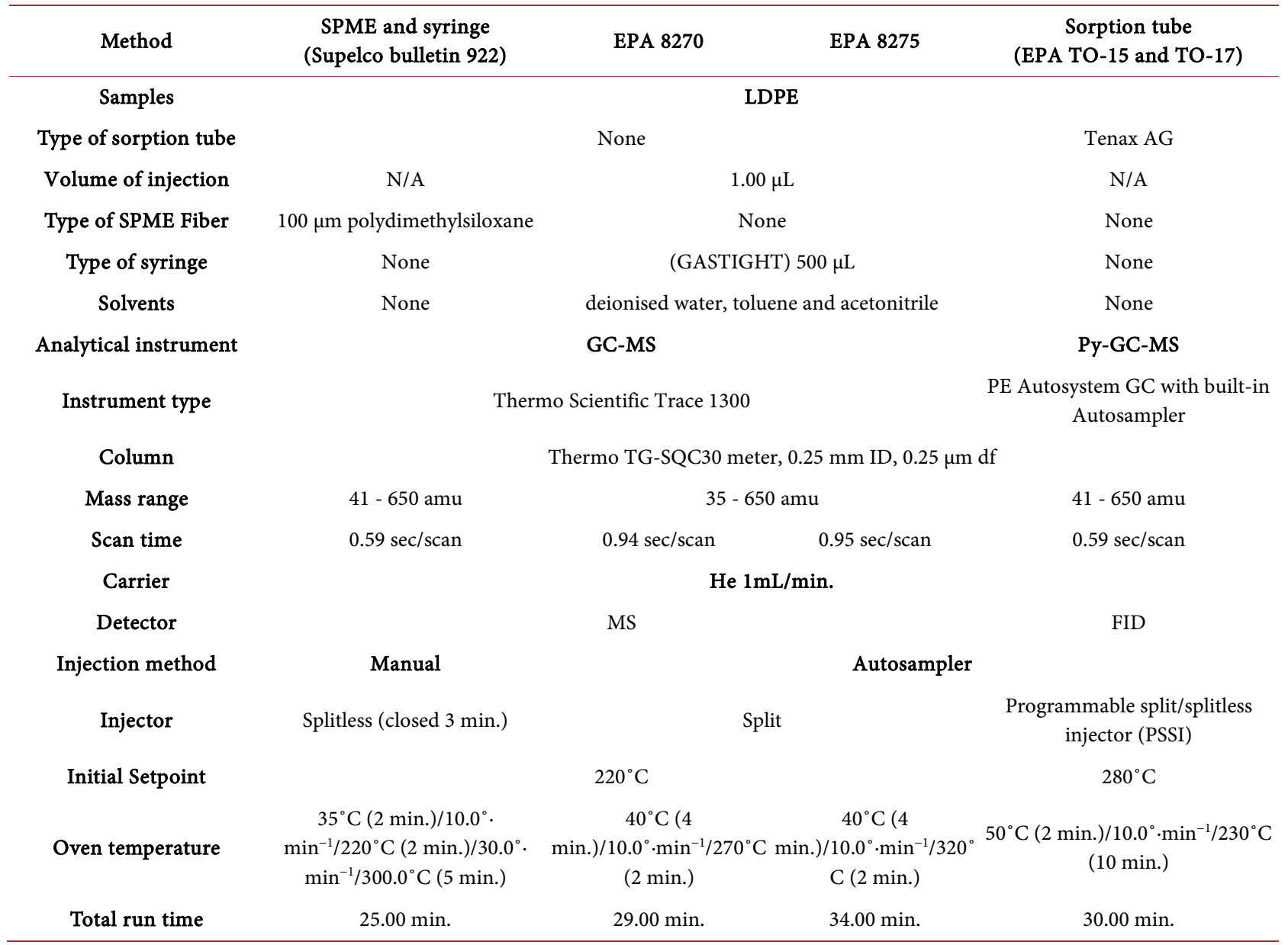


Table 2. Experimental conditions for sampling of aromatic hydrocarbon compounds at furnace temperature $800^{\circ} \mathrm{C}$.

\begin{tabular}{|c|c|c|c|c|c|c|c|c|c|c|}
\hline \multirow[b]{2}{*}{ Methods } & \multicolumn{3}{|c|}{ SPME } & \multicolumn{3}{|c|}{ Syringe } & \multicolumn{3}{|c|}{ Gas-solution absorbers } & \multirow{2}{*}{$\begin{array}{l}\text { Sorption } \\
\text { tube }\end{array}$} \\
\hline & Direct & Tedlar bag* & $\begin{array}{c}\text { Glass sampling } \\
\text { vessel }^{* *}\end{array}$ & Direct & Tedlar bag* & $\begin{array}{l}\text { Glass sampling } \\
\text { vessel }^{* *}\end{array}$ & Toluene & Acetonitrile & $\begin{array}{c}\text { Deionised } \\
\text { water }\end{array}$ & \\
\hline Ignition time & \multicolumn{10}{|c|}{$35 \mathrm{sec}$} \\
\hline Extinction time & \multicolumn{10}{|c|}{ 2:00 min. } \\
\hline Experiment time & \multicolumn{10}{|c|}{ 0:00 to $4: 00 \mathrm{~min}$. } \\
\hline Flow rate & \multicolumn{10}{|c|}{$1 \mathrm{~L} / \mathrm{min}$. } \\
\hline $\begin{array}{l}\text { Sampled volume } \\
\text { of fire effluent }\end{array}$ & \multicolumn{3}{|c|}{ None } & \multicolumn{3}{|c|}{$200 \mu \mathrm{L}$} & \multicolumn{3}{|c|}{$10 \mathrm{~mL}$} & None \\
\hline Sampling time & \multicolumn{3}{|c|}{$\begin{array}{l}\text { 1) Direct SPME sampling was carried } \\
\text { out between 1:20 and 1:30 min. after } \\
\text { ignition time } \\
\text { 2) In case of tedlar bag sampling was } \\
\text { done for } 10 \mathrm{sec} \text {. after end of experiment } \\
\text { 3) In case of glass vessel sampling time } \\
\text { was for 5:00 min. after heating step }\end{array}$} & $\begin{array}{l}\text { 1) Direc } \\
\text { 1:20 mi } \\
\text { 2) In ca } \\
\text { carried } \\
\text { experim } \\
\text { 3) In ca } \\
\text { perform } \\
\text { step }\end{array}$ & $\begin{array}{l}\text { ct syringe sam } \\
\text { in. after ignitic } \\
\text { ase of tedlar ba } \\
\text { out immediat } \\
\text { nent } \\
\text { ase of glass ves } \\
\text { ned immediat }\end{array}$ & $\begin{array}{l}\text { apling was done } \\
\text { on time } \\
\text { ag sampling was } \\
\text { tely after end of } \\
\text { ssel, sampling was } \\
\text { ely after heating }\end{array}$ & \multicolumn{3}{|c|}{$\begin{array}{l}\text { For all solvents, sampling time } \\
\text { was from } 35 \mathrm{sec} \text { to } 3: 30 \mathrm{~min} \text {. }\end{array}$} & $\begin{array}{l}\text { Sampling } \\
\text { time was } \\
\text { from } 35 \mathrm{sec} \\
\text { to } 3: 30 \mathrm{~min} .\end{array}$ \\
\hline
\end{tabular}

${ }^{*}$ Tedlar bags were plugged in all cases after 10 seconds from beginning of experiments; ${ }^{*}$ Glass sampling vessel was heated in oven before sampling for 20 $\min$. at $40^{\circ} \mathrm{C} ;{ }^{* *}$ Sorption tube experiments were carried out, but unfortunately the results were not reproducible.

Table 3. Experimental conditions for sampling of aromatic hydrocarbons compounds at furnace temperature of $600^{\circ} \mathrm{C}$.

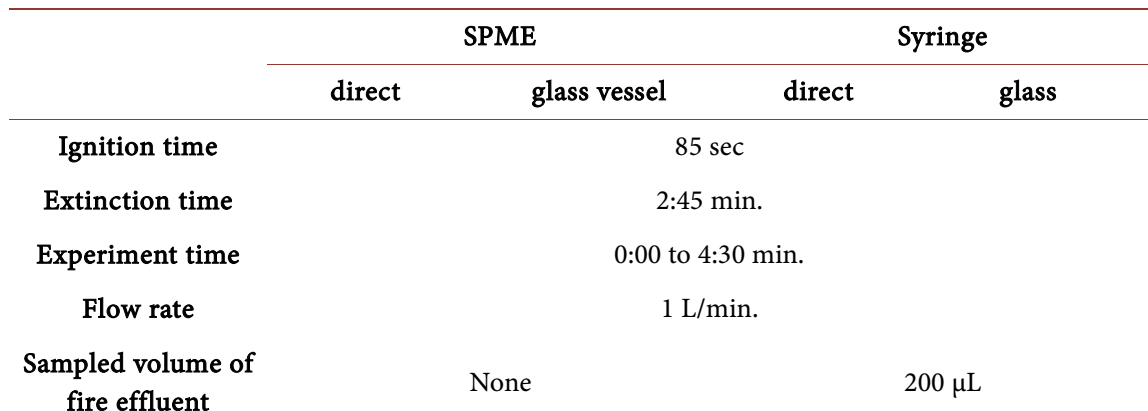

1) Direct SPME sampling was carried out between 2:20 and 2:30 min. after

Sampling time ignition time

2) In case of glass vessel sampling time was for 5:00 min. after heating step
1) Direct syringe sampling was done 2:20 min. after ignition time 2) In case of glass vessel, sampling was performed immediately after heating step

done using midget impingers (Figure 2(F)) [12]. The test atmosphere was drawn or pushed through the absorbing media at a measured rate for a specified period of time. In order to extract a wider range of compounds, three solvents with increasing polarities were used, namely toluene, acetonitrile and deionised water [10]. The three solvents were separately injected as blank samples in the same chromatographic conditions, and no impurities were detected. The experimental conditions corresponding to LDPE combustion are reported in Table 2, while the method used for sampling fire effluents products at $800^{\circ} \mathrm{C}$ are reported in Table 4. 
Table 4. Methods used for collecting fire effluents.

\begin{tabular}{|c|c|c|c|c|c|c|c|c|c|c|c|c|c|}
\hline \multirow{2}{*}{$\begin{array}{l}\text { Sample } \\
\text { Polymer }\end{array}$} & \multirow{2}{*}{$\begin{array}{l}\text { Condition } \\
\text { Air flow/ } \\
\text { temperature }\end{array}$} & \multicolumn{12}{|c|}{ Methods } \\
\hline & & \multicolumn{2}{|c|}{$\begin{array}{l}\text { gas-solution } \\
\text { absorbers } \\
\text { (EPA 8270) }\end{array}$} & \multicolumn{3}{|c|}{$\begin{array}{c}\text { gas-solution } \\
\text { absorbers } \\
\text { (EPA 8275) }\end{array}$} & $\begin{array}{c}\text { SPME } \\
\text { (direct) }\end{array}$ & \multirow[t]{2}{*}{$\begin{array}{l}\text { SPME (gas } \\
\text { sampling bulb } \\
250 \mathrm{~mL} \text { ) }\end{array}$} & \multirow[t]{2}{*}{$\begin{array}{c}\text { SPME } \\
\text { (tedlar bag) }\end{array}$} & \multirow[t]{2}{*}{$\begin{array}{l}\text { Syringe } \\
\text { (direct) }\end{array}$} & \multirow[t]{2}{*}{$\begin{array}{c}\text { Syringe (gas } \\
\text { sampling bulb } \\
250 \mathrm{~mL} \text { ) }\end{array}$} & $\begin{array}{l}\text { Syringe } \\
\text { (tedlar bag) }\end{array}$ & $\begin{array}{l}\text { Sorption } \\
\text { tube }\end{array}$ \\
\hline & & Successful & test & Succ & cessful & I test & & & & & & & \\
\hline $\begin{array}{l}\text { LDPE } \\
\text { (NFX) }\end{array}$ & $\begin{array}{l}2 \mathrm{~L} \cdot \mathrm{min}^{-1} / \\
800^{\circ} \mathrm{C}\end{array}$ & 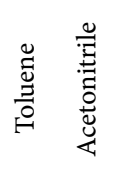 & 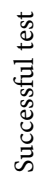 & 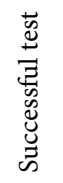 & 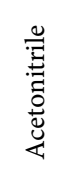 & 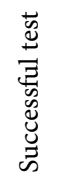 & $\begin{array}{c}\text { Successful } \\
\text { test }\end{array}$ & $\begin{array}{c}\text { Successful } \\
\text { test }\end{array}$ & $\begin{array}{c}\text { No } \\
\text { detectable } \\
\text { peaks }\end{array}$ & $\begin{array}{c}\text { Successful } \\
\text { test }\end{array}$ & $\begin{array}{c}\text { Successful } \\
\text { test }\end{array}$ & $\begin{array}{c}\text { No } \\
\text { detectable } \\
\text { peaks }\end{array}$ & $\begin{array}{c}\text { No } \\
\text { detectable } \\
\text { peaks }\end{array}$ \\
\hline $\begin{array}{l}\text { LDPE } \\
\text { (NFX) }\end{array}$ & $\begin{array}{l}2 \mathrm{~L} \cdot \mathrm{min}^{-1} / \\
600^{\circ} \mathrm{C}\end{array}$ & No test & & & No tes & & $\begin{array}{l}\text { Successful } \\
\text { test }\end{array}$ & $\begin{array}{c}\text { Successful } \\
\text { test }\end{array}$ & No test & $\begin{array}{c}\text { Successful } \\
\text { test }\end{array}$ & $\begin{array}{c}\text { Successful } \\
\text { test }\end{array}$ & No test & No test \\
\hline
\end{tabular}

\subsection{Sampling Using Solid Phase Micro Extraction (SPME)}

Sampling with SPME (Figure $2(\mathrm{C})$ ) is widely used for many analytical applications. It is an easy and convenient technique applied as an extraction and concentration step prior to GC-MS. The test atmosphere is pumped at a constant rate then sampled with SPME device either directly or after being collected using a tedlar bag (Figure 2(B)) [12] [21]. In addition, we have also developed a procedure for collecting the fire effluents into a glass vessel equipped with two valves before sampling with SPME. In this method, the volatile species were flowed through a $250 \mathrm{~mL}$ glass sampling vessel. This glass bulb (shown in Figure $2(\mathrm{~A}))$ was then heated at $40^{\circ} \mathrm{C}$ for 20 minutes; after that the aromatic hydrocarbons were sampled by SPME for 5 minutes. In case of using the tedlar bag, it is necessary to filter the gas effluent to remove particulates and avoid inlet plugging; for this purpose glass wool filters, have been found effective [12].

\subsection{Sampling Using Syringe}

We have developed a simpler and more efficient sampling method of fire effluents using a gas syringe (Figure $2(\mathrm{E})$ ). It proved to be a good alternative to SPME for collecting combustion products; it is easier and faster, allowing a rapid injection into GC-MS. Furthermore, it can save both cost and time of analysis. The combustion products are taken either directly using a gas syringe or after being collected in a $250 \mathrm{~mL}$ glass sampling vessel as mentioned earlier. After collecting these volatile species in a glass bulb, it was heated in an oven at $40^{\circ} \mathrm{C}$ for 20 minutes; after that the aromatic hydrocarbons were directly sampled using a $200 \mu \mathrm{L}$ gas syringe [12].

\subsection{Sampling Using Solid Sorption Tubes}

The sampling using solid sorption tubes (Figure 2(D)) was carried out with a pyrolysis unit connected to a GC-MS instrument (Py-GC-MS). The sorption tube was packed with Tenax AG sorbent. The main problem we encountered when using this technique was that inlet plugging can occur due to soot accu- 
mulation. In this case, a decrease in sample flow rate was observed [9] [12] [13].

\subsection{Sampling Using Tedlar Bags}

Tedlar bag (Figure 2(B)) is made of a polyvinyl fluoride film (PVF) and equipped with a polytetrafluoroethylene (Teflon, PTFE) valve. It is used to collect various gas samples such as volatile organic compounds (VOCs). Tedlar film (PVF) is a polymer resistant to high temperature; it can be used up to $170^{\circ} \mathrm{C}$. Moreover, it is chemically inert, resistant to corrosion with low absorption and permeability of gases [12]. However, in our experiments tedlar bags were plugged in all cases after only 10 seconds from beginning of experiment.

\subsection{Analysis of LDPE Combustion Products}

Two instruments were used for analysing aromatic hydrocarbons after sampling them by different methods: GC-MS model Thermo Scientific (USA) Trace 1300 and Py-GC-MS model PE Autosystem GC (Perkin Elmer, USA) with built-in Autosampler. On the other hand, all the experimental parameters were set according to previous studies [12] [19] [20].

\section{Results and Discussion}

All experiments at $800^{\circ} \mathrm{C}$ were done in duplicate except those using sorption tubes and tedlar bags which did not show detectable combustion products compared with other methods. It appeared that the best results were obtained by using SPME and syringe, either directly or with glass vessel, while the other sampling techniques were unfruitful. Thus, the investigations using SPME and syringe which gave the best results were repeated with a furnace temperature of $600^{\circ} \mathrm{C}$, as shown in Table 4.

The LDPE samples were burnt at $800^{\circ} \mathrm{C}$ and $600^{\circ} \mathrm{C}$ using a toxicity tube furnace NF X70-100. The results reported in Table 2 and Table 3, show that the burning process was much faster at $800^{\circ} \mathrm{C}$ than at $600^{\circ} \mathrm{C}$; the ignition time which corresponds to the beginning of burning was $35 \mathrm{~s}$. at $800^{\circ} \mathrm{C}$ instead of $85 \mathrm{~s}$. at $600^{\circ} \mathrm{C}$. Similarly the extinction time corresponding to the end of LDPE combustion was $2: 00$ and $2: 45 \mathrm{~min}$. at $800^{\circ} \mathrm{C}$ and $600^{\circ} \mathrm{C}$, respectively. For this reason, the selected sampling conditions were adapted according to the combustion rate at each temperature as indicated in both tables. As an example, the sampling time when using both SPME and syringe was 1:20 and 2:20 min., at $800^{\circ} \mathrm{C}$ and $600^{\circ} \mathrm{C}$, respectively. The collection of aromatic hydrocarbons produced by LDPE burning was performed by different methods of sampling such as SPME, syringe, gas-solution absorbers and sorption tubes. The results obtained in fire effluent analysis are shown in Figure 3 and Figure 4, and in Table 5 and Table 6.

\subsection{Aromatic Hydrocarbons Produced at $800^{\circ} \mathrm{C}$}

Burning LDPE at $800^{\circ} \mathrm{C}$ can be considered as under-ventilated process; at this 


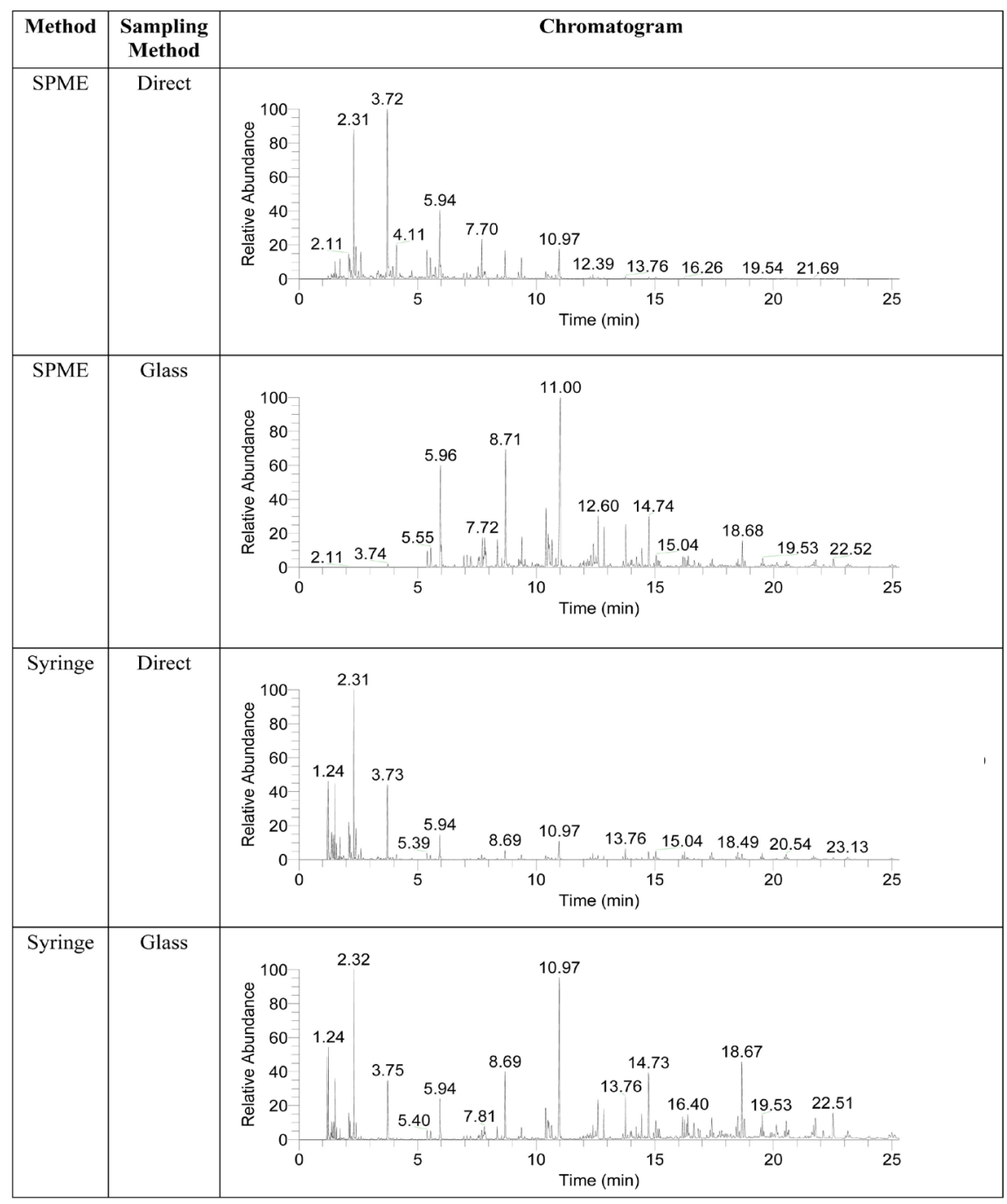

Figure 3. Chromatograms of aroatic hydrocarbons extracted by SPME and syringe at $800^{\circ} \mathrm{C}$.

temperature, three solvents were used for sampling with gas-solution absorbers (midget impingers) according to procedures EPA 8270 and 8275 at $800^{\circ} \mathrm{C}$. These solvents were: deionized water, toluene and acetonitrile. No hydrocarbon compounds were detected in the deionized water extract, due to the low polarity of hydrocarbons compared to water; whereas acetonitrile and toluene which are less polar, allowed collection of few aromatic hydrocarbons. Nevertheless, all the results obtained with gas-solution absorbers according to whether EPA 8270 or EPA 8275 procedures were not satisfactory. Figure 3 shows the results obtained by collection with SPME and syringe, either directly or using glass sampling vessel at $800^{\circ} \mathrm{C}$.

In case of direct sampling both techniques showed that intensity of volatile compounds was higher than that of the heavy products, whereas using glass sampling vessel gave higher intensity for the heavier hydrocarbons. On the other hand, as mentioned in Table 2 and Table 4, the results obtained with sorption 


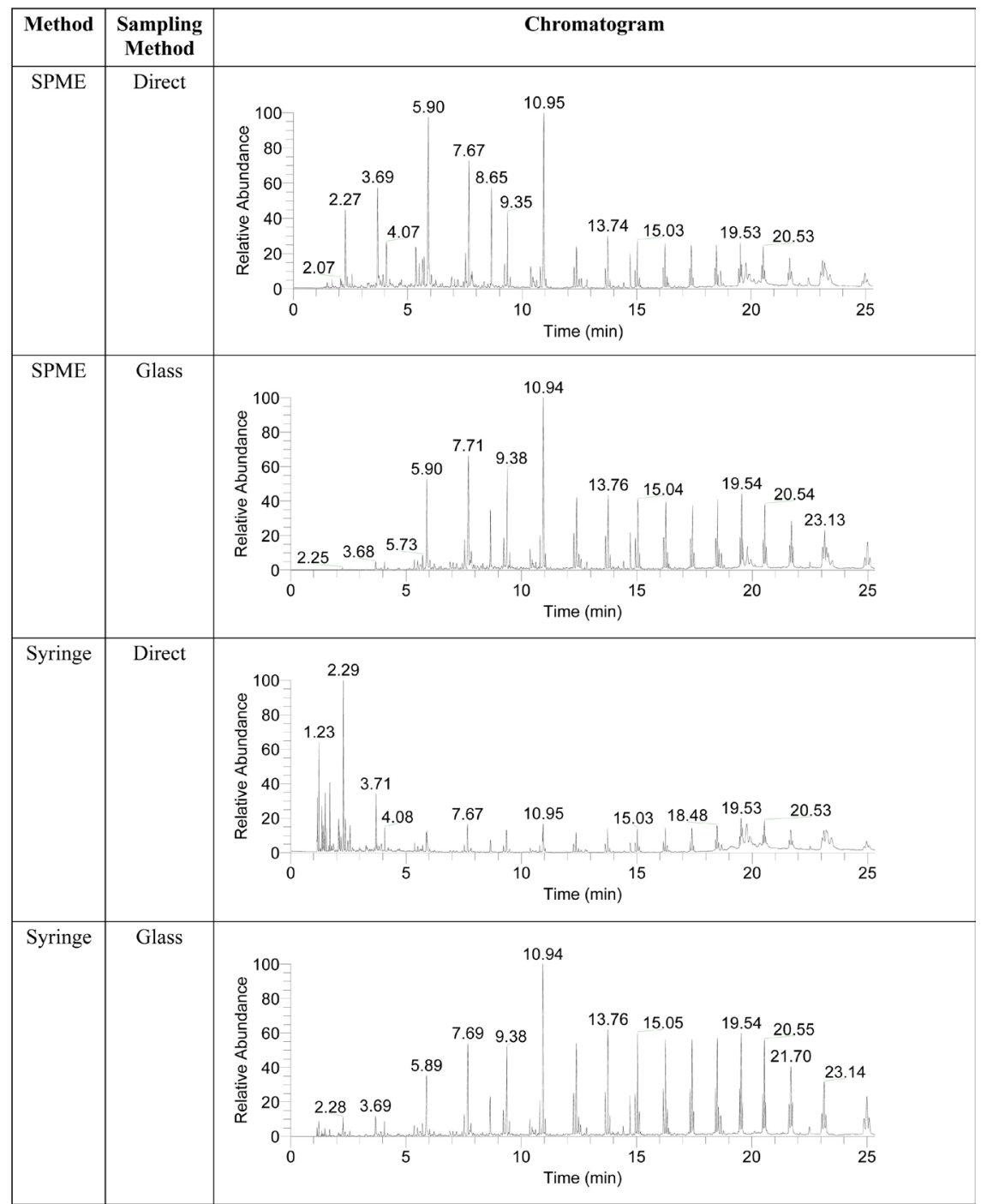

Figure 4. Chromatograms of aromatic hydrocarbons extracted by SPME and syringe at $600^{\circ} \mathrm{C}$.

Table 5. Summary of aromatic hydrocarbons detected after burning LDPE at $800^{\circ} \mathrm{C}$ and sampled with SPME and syringe methods.

\begin{tabular}{|c|c|c|c|c|c|c|c|}
\hline PAHs & MW & Structure & $\begin{array}{l}\text { Retention } \\
\text { time (min.) }\end{array}$ & $\begin{array}{l}\text { SPME } \\
\text { direct }\end{array}$ & $\begin{array}{c}\text { SPME } \\
\text { glass }\end{array}$ & $\begin{array}{l}\text { Syringe } \\
\text { direct }\end{array}$ & $\begin{array}{c}\text { Syringe } \\
\text { glass }\end{array}$ \\
\hline 1,4-cyclohexadiene & 80 & & 2.07 & $\sqrt{ }$ & $\mathrm{X}$ & $\sqrt{ }$ & $\sqrt{ }$ \\
\hline Benzene & 78 & & 2.27 & $\sqrt{ }$ & $\sqrt{ }$ & $\sqrt{ }$ & $\sqrt{ }$ \\
\hline Toluene & 92 & & 3.70 & $\sqrt{ }$ & $\sqrt{ }$ & $\sqrt{ }$ & $\sqrt{ }$ \\
\hline Styrene & 104 & & 5.91 & $\sqrt{ }$ & $\sqrt{ }$ & $\sqrt{ }$ & $\sqrt{ }$ \\
\hline Ethyl benzene & 106 & & 7.63 & $\sqrt{ }$ & $\sqrt{ }$ & $\sqrt{ }$ & $\sqrt{ }$ \\
\hline Indene & 116 & & 8.64 & $\sqrt{ }$ & $\sqrt{ }$ & $\sqrt{ }$ & $\sqrt{ }$ \\
\hline Benzene, propyl & 120 & & 8.68 & $\sqrt{ }$ & $\sqrt{ }$ & $\mathrm{X}$ & $\sqrt{ }$ \\
\hline
\end{tabular}




\section{Continued}

Indane
Naphthalene,
Naphthihydro

Table 6. Summary of aromatic hydrocarbons detected after burning LDPE at $600^{\circ} \mathrm{C}$ and sampled with SPME and syringe methods.

\begin{tabular}{|c|c|c|c|c|c|c|c|}
\hline PAHs & MW & Structure & $\begin{array}{l}\text { Retention } \\
\text { time (min.) }\end{array}$ & $\begin{array}{l}\text { SPME } \\
\text { direct }\end{array}$ & $\begin{array}{l}\text { SPME } \\
\text { glass }\end{array}$ & $\begin{array}{c}\text { Syringe } \\
\text { direct }\end{array}$ & $\begin{array}{c}\text { Syringe } \\
\text { glass }\end{array}$ \\
\hline 1,4-Cyclohexadiene & 80 & & 2.07 & $\sqrt{ }$ & $\mathrm{X}$ & $\sqrt{ }$ & $\sqrt{ }$ \\
\hline Benzene & 78 & & 2.27 & $\sqrt{ }$ & $\sqrt{ }$ & $\sqrt{ }$ & $\sqrt{ }$ \\
\hline Toluene & 92 & & 3.70 & $\sqrt{ }$ & $\sqrt{ }$ & $\sqrt{ }$ & $\sqrt{ }$ \\
\hline Styrene & 104 & & 5.91 & $\sqrt{ }$ & $\sqrt{ }$ & $\sqrt{ }$ & $\sqrt{ }$ \\
\hline Ethyl benzene & 106 & & 7.63 & $\sqrt{ }$ & $\sqrt{ }$ & $\sqrt{ }$ & $\sqrt{ }$ \\
\hline Indene & 116 & & 8.64 & $\sqrt{ }$ & $\sqrt{ }$ & $\sqrt{ }$ & $\sqrt{ }$ \\
\hline Benzene, propyl & 120 & & 8.68 & $\sqrt{ }$ & $\sqrt{ }$ & $\mathrm{X}$ & $\sqrt{ }$ \\
\hline Indane & 118 & & 9.34 & $\mathrm{X}$ & $\sqrt{ }$ & $\sqrt{ }$ & $\sqrt{ }$ \\
\hline $\begin{array}{l}\text { Naphthalene, } \\
\text { 1,2dihydro }\end{array}$ & 130 & & 10.36 & $\sqrt{ }$ & $\sqrt{ }$ & $\sqrt{ }$ & $\sqrt{ }$ \\
\hline Naphthalene & 128 & & 10.95 & $\sqrt{ }$ & $\sqrt{ }$ & $\sqrt{ }$ & $\sqrt{ }$ \\
\hline $\begin{array}{l}\text { Naphthalene, } \\
\text { 1-methyl }\end{array}$ & 142 & & 12.59 & $\sqrt{ }$ & $\sqrt{ }$ & $\sqrt{ }$ & $\sqrt{ }$ \\
\hline Biphenylene & 152 & & 14.72 & $\sqrt{ }$ & $\sqrt{ }$ & $\sqrt{ }$ & $\sqrt{ }$ \\
\hline Biphenyl & 154 & & 13.74 & $\mathrm{X}$ & $\sqrt{ }$ & $\mathrm{X}$ & $\sqrt{ }$ \\
\hline Anthracene & 178 & & 18.64 & $\sqrt{ }$ & $\sqrt{ }$ & $\sqrt{ }$ & $\sqrt{ }$ \\
\hline Pyrene & 202 & & 22.45 & $\sqrt{ }$ & $\sqrt{ }$ & $\sqrt{ }$ & $\sqrt{ }$ \\
\hline
\end{tabular}


tubes were not reproducible, while tedlar bags were plugged in all cases after only 10 seconds from the beginning of experiment. Table 5 shows the aromatic hydrocarbons identified in all experiments carried out at $800^{\circ} \mathrm{C}$, using the different sampling methods mentioned in Figure 3. As reported above, the best results for collection of aromatic hydrocarbons resulting from LDPE burning were obtained using SPME and syringe, which allowed detection of 13 to 15 hydrocarbons. In contrast, the intensity of all peaks extracted using midget impinger with both acetonitrile and toluene was very low, in comparison with the results of collection by SPME and syringe. In case of using deionized water for sampling, only styrene was detected. To summarize, the most convenient method was sampling by syringe with a glass vessel which enabled detection of fifteen aromatic hydrocarbons, as reported in Table 5. Among the identified combustion products produced by burning LDPE at $800^{\circ} \mathrm{C}$, three are considered as priority aromatic hydrocarbons: naphthalene, anthracene and pyrene. Their carcinogenic toxic equivalency factor (TEF) values are $0.001,0.01$ and 0.001 , respectively [11].

\subsection{Aromatic Hydrocarbons Produced at $600^{\circ} \mathrm{C}$}

As mentioned earlier, the results obtained after LDPE burning at $800^{\circ} \mathrm{C}$ were not satisfactory when using sampling with sorption tube, tedlar bag and gas-solution absorbers. Moreover, these sampling techniques were time consuming and their setting needs more efforts, thus they were not used for experiments carried out at $600^{\circ} \mathrm{C}$. Therefore, the only sampling methods conducted at $600^{\circ} \mathrm{C}$ which correspond to well-ventilated conditions were SPME and syringe, either direct or with glass vessel. Figure 4 shows the results obtained by SPME and syringe, using both methods.

As it was observed in Figure 3, direct sampling using both techniques showed that intensity of volatile compounds was higher than that of the heavy products, whereas using glass sampling vessel gave more intense peaks for the heavier hydrocarbons. On the other hand, the intensity of all hydrocarbon peaks observed after burning at $600^{\circ} \mathrm{C}$ was higher than that obtained at $800^{\circ} \mathrm{C}$; this is clearly due to the higher combustion rate of LDPE at $600^{\circ} \mathrm{C}$, corresponding to well-ventilated conditions, because the burning time was longer and availability of oxygen was higher. Table 6 shows the aromatic hydrocarbons identified in all experiments carried out at $600^{\circ} \mathrm{C}$, using the different sampling methods mentioned in Figure 4. As reported above, the best results for collection of aromatic hydrocarbons resulting from LDPE burning were obtained using SPME and syringe, which allowed detection of 13 to 15 aromatic hydrocarbons. To summarize, the most convenient method was sampling by syringe with a glass vessel which showed the presence of fifteen aromatic hydrocarbons. These results are in agreement with those obtained at burning LDPE at $800^{\circ} \mathrm{C}$. Combustion of LDPE at $600^{\circ} \mathrm{C}$ yielded several aromatic hydrocarbons, among which three are listed as priority aromatic hydrocarbons: naphthalene, anthracene and pyrene whose carcinogen- 
ic toxic equivalency factor (TEF) values are $0.001,0.01$ and 0.001 , respectively [11].

\section{Conclusions}

The aromatic hydrocarbons emitted from burning $1 \mathrm{~g}$ of LDPE have been investigated by using five different sampling methods under various fire conditions. The main gas phase components were sampled and analysed in small-scale tests using a toxicity tube furnace. The used sampling methods were: solid phase micro-extraction (SPME), syringe, sorption tubes, gas-solution absorbers (midget impingers) and tedlar bags, while the combustion products were analysed by GC-MS and Py-GC-MS. Collection of the fire effluents by syringe and SPME was carried out either by direct sampling or using a glass vessel. In this case, the identification of aromatic hydrocarbons produced showed that fifteen hydrocarbons were detected in significant concentrations, some of them having a potentially negative impact on the environment, or human health. The sampling method using syringe with a glass vessel showed the best results, as it gave the highest detection of aromatic hydrocarbons at 800 and $600^{\circ} \mathrm{C}$; then followed by solid-phase microextraction. However, the intensity of the volatile detected hydrocarbons was higher at $600^{\circ} \mathrm{C}$ than for $800^{\circ} \mathrm{C}$ which corresponds to under-ventilated conditions. Gas-solution absorber (midget impinger) was also used with toluene, acetonitrile and deionised water as solvents with increasing polarity; it showed poorer results compared with syringe and SPME methods.

In addition, some experiments were performed using tedlar bags and sorption tubes, but they did not give satisfactory results, either because of plugged orifice or non-reproducible results. After burning LDPE and analysing its combustion products, benzene, naphthalene, anthracene and pyrene were among the identified hydrocarbons. They are considered as carcinogenic or possibly carcinogenic compounds.

\section{Acknowledgements}

The Authors extend their appreciation to King Fahad Security College (Riyadh, Kingdom of Saudi Arabia) for supporting this work and also to Centre for Fire Hazards and Science, University of Central Lancashire, Preston (United Kingdom) and all staff for their contribution.

\section{Conflicts of Interest}

The authors declare no conflicts of interest regarding the publication of this paper.

\section{References}

[1] Dhabbah, A.M. (2015) Ways of Analysis of Fire Effluents and Assessment of Toxic Hazards. Journal of Analytical Sciences, Methods and Instrumentation, 5, 1-12. https://doi.org/10.4236/jasmi.2015.51001 
[2] Gann, R. (2008) Fire Effluent, People, and Standards: Standardization Philosophy for the Effects of Fire Effluent on Human Tenability. Conference on Hazards of Combustion Products, London, 10-11 November 2008.

[3] Purser, D. (1992) The Evolution of Toxic Effluents in Fires and the Assessment of Toxic Hazard. Toxicology Letters, 64-65, 247-255. https://doi.org/10.1016/0378-4274(92)90196-Q

[4] Hull, T.R., Brein, D. and Stec, A.A. (2016) Quantification of Toxic Hazard from Fires in Buildings. Journal of Building Engineering, 8, 313-318. https://doi.org/10.1016/j.jobe.2016.02.014

[5] Purser, D.A. (2010) Hazards from Smoke and Irritants. In: Stec, A.A. and Hull, T.R., Eds., Fire Toxicity, Woodhead Publishing, Cambridge, 51-117. https://doi.org/10.1533/9781845698072.2.51

[6] Hull, T.R. and Stec, A.A., (2010) Introduction to fire Toxicity. In: Stec, A.A. and Hull, T.R., Eds., Fire Toxicity, Woodhead Publishing, Cambridge, 3-25. https://doi.org/10.1533/9781845698072.1.3

[7] Stec, A.A. (2010) Experimental Methods in Combustion Toxicology. In: Stec, A.A. and Hull, T.R., Eds., Fire Toxicity, Woodhead Publishing, Cambridge, 217-228. https://doi.org/10.1533/9781845698072.3.217

[8] Purser, D. (2008) Assessment of Hazards to Occupants from Smoke, Toxic Gases, and Heat. In: Hurley, M, Ed., SFPE Handbook of Fire Protection Engineering, Springer-Verlag, New York, 2-96.

[9] Blomqvist, P., McNamee, M.S., Andersson P. and Lönnermark, A. (2011) Polycyclic Aromatic Hydrocarbons (PAHs) Quantified in Large-Scale Fire Experiments. Fire Technology Journal, 48, 513-528. https://doi.org/10.1007/s10694-011-0242-9

[10] Fardell, P. and Guillaume, E. (2010) Sampling and Measurement of Toxic Fire Effluent. In: Stec, A.A. and Hull, T.R., Eds., Fire Toxicity, 1st Edition, Woodhead Publishing, Cambridge, 385-423. https://doi.org/10.1533/9781845698072.4.385

[11] Public Health England (PHE) (2017) Contaminated Land Information Sheet: Risk Assessment Approaches for Polycyclic Aromatic Hydrocarbons (PAHs). London. https://assets.publishing.service.gov.uk/government/uploads/system/uploads/attach ment_data/file/671075/Contaminated_land_information_sheet_PAHs.pdf

[12] BS (2013) ISO 19701:2013 Methods for Sampling and Analysis of Fire Effluents. London.

[13] Hull, T.R. (2010) Bench-Scale Generation of Fire Effluents. In: Stec, A. and Hull, R., Eds., Fire Toxicity, Woodhead Publishing, 424-460. https://doi.org/10.1533/9781845698072.4.424

[14] AFNOR (2006) NF X70-100-1, Fire Tests-Analysis of Gaseous Effluents-Part 1: Methods for Analysing Gases Stemming from Thermal Degradation.

[15] SKC (2000) Sample Setup Guide-Impingers. https://www.skcinc.com/catalog/pdf/instructions/1165.pdf

[16] Arthur, C.L. and Pawliszyn, J. (1990) Solid Phase Microextraction with Thermal Desorption Using Fused Silica Optical Fibers. Analytical Chemistry, 62, 2145-2148. https://doi.org/10.1021/ac00218a019

[17] Vas, G. and Vékey, K. (2004) Solid-Phase Microextraction: A Powerful Sample Preparation Tool Prior to Mass Spectrometric Analysis. Journal of Mass Spectrometry, 39, 233-254. https://doi.org/10.1002/jms.606

[18] RESTEK (2008) Thermal Desorption Tubes: Versatile Air Sampling for a Wide Range of Applications. http://www.restek.com/pdfs/EVFL1065.pdf 
[19] Sahil, K., Prashant, B., Akanksha, M., Premjeet, S. and Devashish, R. (2011) Gas Chromatography-Mass Spectrometry (GC-MS) Applications. International Journal of Pharmaceutical and Biological Archive, 2, 1544-1560.

[20] Ma, X.-M., Lu, R. and Miyakoshi, T. (2014) Application of Pyrolysis Gas Chromatography/Mass Spectrometry in Lacquer Research: A Review. Polymers (Basel), 6, 132-144. https://doi.org/10.3390/polym6010132

[21] Supelco Bulletin (1998) SPME/GC for Forensic Applications: Explosives, Fire Debris, and Drugs of Abuse.

https://www.sigmaaldrich.com/Graphics/Supelco/objects/4600/4546.pdf

[22] US-EPA (2014) Semivolatile Organic Compounds by Gas Chromatography/Mass Spectrometry (GC/MS). Method 8270.

https://www.epa.gov/sites/production/files/2015-07/documents/epa-8270d.pdf

[23] US EPA (1996) Semivolatile Organic Compounds (PAHs AND PCBs) in Soils/Sludges and Solid Wastes Using Thermal Extraction/Gas Chromatography/Mass Spectrometry (TE/GC/MS). Method 8275A.

https://www.epa.gov/sites/production/files/2015-12/documents/8275a.pdf

[24] EPA (1999) Method TO-15: Determination of Volatile Organic Compounds (VOCs) in Air Collected in Specially-Prepared Canisters and Analyzed by Gas Chromatography/Mass Spectrometry (GC/MS).

[25] EPA (1999) Method TO-17: Determination of Volatile Organic Compounds in Ambient Air Using Active Sampling onto Sorbent Tubes. 